\title{
The association between serum TSH concentration and thyroid cancer
}

\author{
Kristien Boelaert
}

School of Clinical and Experimental Medicine, College of Medical and Dental Sciences, Institute of Biomedical Research, University of Birmingham, IBR Building 2nd Floor, Edgbaston, Birmingham B15 2TT, UK

(Correspondence should be addressed to K Boelaert; Email: k.boelaert@bham.ac.uk)

\begin{abstract}
There is mounting evidence that the serum concentration of TSH is an independent predictor for the diagnosis of thyroid malignancy in patients with nodular thyroid disease. Furthermore, preoperative serum TSH concentrations are higher in patients with more aggressive tumours, suggesting a potential role for TSH in the progression of differentiated thyroid cancer. Based on these observations, patients with higher serum TSH concentrations and borderline cytological results may require more aggressive investigation and treatment when compared with those with lower baseline TSH levels. The mechanisms underlying the finding of higher serum TSH in patients with thyroid cancer remain unexplained. In this issue of Endocrine-Related Cancer, Fiore et al. have analysed the relationship between serum TSH and diagnosis of papillary thyroid cancer in 10178 patients with nodular thyroid disease who were investigated by fine-needle aspiration biopsy. They found significantly higher TSH concentrations in patients who were subsequently diagnosed with thyroid cancer compared with those with benign disease. In addition, they found that the development of autonomous thyroid function $(\mathrm{TSH}<0.4 \mu \mathrm{U} / \mathrm{ml}$ ) was associated with a reduction in the risk of papillary thyroid carcinoma. In this commentary, the evidence regarding the association between serum TSH and thyroid cancer is discussed placing these new findings into context.
\end{abstract}

Endocrine-Related Cancer (2009) 16 1065-1072

\section{Introduction}

Thyroid cancer is the most common endocrine malignancy and its incidence continues to rise. Between 1973 and 2002, there was a 2.4-fold increase in thyroid cancer and a 2.9-fold rise in papillary thyroid cancer (PTC) diagnoses in the United States (Davies \& Welch 2006). Thyroid carcinoma, in most cases, presents clinically as a solitary nodule or as a dominant nodule within a multinodular thyroid gland. In the general population, thyroid nodules are very common with reported prevalences of palpable nodules in 4-7\% of adults (Vander et al. 1968, Tunbridge et al. 1977, Hegedus 2004). Additionally, high resolution ultrasound can detect thyroid nodules in $19-67 \%$ of individuals, being most common in women and in the elderly (Marqusee et al. 2000, Hegedus et al. 2003, Reiners et al. 2004). The challenge to clinicians is to identify the minority of thyroid nodules $(5-15 \%)$ that harbour malignancy from the majority, which can be managed conservatively.
There are a number of well-established predictors of malignancy in thyroid nodules, including the finding of hard and fixed lesions on clinical examination, rapid growth of nodules, associated hoarseness, dysphagia or lymphadenopathy, although all of these symptoms and signs are relatively uncommon at diagnosis (Hegedus et al. 2003, Hegedus 2004). Further risk factors include young $(<20$ years) or old age $(>70$ years), male gender (Belfiore et al. 1992) and history of irradiation exposure (Ron et al. 1995). More recently, a number of studies have suggested that higher concentrations of $\mathrm{TSH}$, even within the normal range, are associated with a subsequent diagnosis of thyroid cancer in patients presenting with thyroid nodules (Table 1; Boelaert et al. 2006, Jonklaas et al. 2008, Polyzos et al. 2008). Moreover, higher serum TSH levels have been found associated with advanced stages of thyroid cancer (Haymart et al. 2008a). These findings suggest that TSH may play a central role in the development and/or progression of thyroid carcinomas. 
Table 1 Summary table of studies investigating the relationship between serum TSH concentration and thyroid cancer

\begin{tabular}{|c|c|c|c|c|c|}
\hline Authors & Journal & $\begin{array}{l}\text { No. of } \\
\text { patients } \\
\text { studied }\end{array}$ & $\begin{array}{l}\text { Country } \\
\text { of study }\end{array}$ & $\begin{array}{l}\text { Date of } \\
\text { publication }\end{array}$ & Significant findings \\
\hline $\begin{array}{l}\text { Boelaert et al. } \\
\quad(2006)\end{array}$ & $\begin{array}{l}\text { Journal of Clinical } \\
\text { Endocrinology and } \\
\text { Metabolism }\end{array}$ & 1500 & UK & November 2006 & $\begin{array}{l}\text { Serum TSH is independent predictor } \\
\text { of malignancy in thyroid nodules } \\
\text { Risk of malignancy rises in parallel with } \\
\text { serum TSH within normal range }\end{array}$ \\
\hline $\begin{array}{l}\text { Haymart et al. } \\
\qquad(2008 a)\end{array}$ & $\begin{array}{l}\text { Journal of Clinical } \\
\text { Endocrinology and } \\
\text { Metabolism }\end{array}$ & 843 & US & March 2008 & $\begin{array}{l}\text { Likelihood of thyroid cancer increases } \\
\text { with higher TSH concentration } \\
\text { Higher serum TSH associated with } \\
\text { advanced stage-differentiated } \\
\text { thyroid cancer }\end{array}$ \\
\hline $\begin{array}{l}\text { Jonklaas et al. } \\
\quad(2008)\end{array}$ & Thyroid & 50 & US & September 2008 & $\begin{array}{l}\text { Higher TSH concentrations are } \\
\text { associated with diagnosis of thyroid } \\
\text { cancer } \\
\text { Patients with thyroid cancer have lower } \\
\text { serum total } \mathrm{T}_{3} \text { concentrations }\end{array}$ \\
\hline $\begin{array}{l}\text { Polyzos et al. } \\
\text { (2008) }\end{array}$ & $\begin{array}{l}\text { Journal of Cancer } \\
\text { Research and } \\
\text { Clinical Oncology }\end{array}$ & 565 & Greece & September 2008 & $\begin{array}{l}\text { Higher rates of thyroid malignancy in } \\
\text { patients with } \mathrm{TSH} \text { in upper tertile of } \\
\text { normal range }\end{array}$ \\
\hline $\begin{array}{l}\text { Haymart et al. } \\
\qquad(2008 b)\end{array}$ & Clinical Endocrinology & 1361 & US & $\begin{array}{l}\text { December } 2008 \\
\quad \text { (Epub) }\end{array}$ & $\begin{array}{l}\text { Thyroid cancer incidence correlates } \\
\text { with serum TSH independent } \\
\text { of age } \\
\text { Higher TSH is associated with extra- } \\
\text { thyroidal extension of disease }\end{array}$ \\
\hline $\begin{array}{l}\text { Fiore et al. } \\
\text { (2009) }\end{array}$ & $\begin{array}{l}\text { Endocrine-Related } \\
\text { Cancer }\end{array}$ & 10178 & Italy & September 2009 & $\begin{array}{l}\text { Higher TSH in patients with T3-T4 } \\
\text { disease and in those with lymph } \\
\text { node metastases } \\
\text { Autonomously functioning thyroid } \\
\text { nodules are less likely to be } \\
\text { malignant }\end{array}$ \\
\hline
\end{tabular}

TSH is a well-established growth factor for thyroid nodules, and suppression of serum TSH concentrations by administering exogenous thyroid hormone may inhibit the growth of established nodules as well as the development of new thyroid nodules (Papini et al. 1998). Moreover, therapy with suppressive doses of thyroxine $\left(\mathrm{T}_{4}\right)$ has long been known to positively affect outcomes in differentiated thyroid cancer (Mazzaferri \& Jhiang 1994), and retrospective studies have shown that TSH suppression is an independent predictor of recurrence of differentiated thyroid cancer (Pujol et al. 1996). More recently, prospective studies have indicated reductions in thyroid carcinoma-related death and relapse with aggressive TSH suppression, especially in high-risk patients (Jonklaas et al. 2006, Hovens et al. 2007). Based on these findings, it is plausible that the higher rates of malignancy with increasing serum TSH concentrations reflect a tropic effect of TSH on thyroid tissue promoting neoplasia and carcinogenesis. Iodine deficiency causes a reduction in the level of circulating thyroid hormones associated with a consequent rise in serum $\mathrm{TSH}$ concentrations, and chronic iodine deficiency is a well-established risk factor for the development of goitre and follicular thyroid carcinoma (Belfiore et al. 1992, Franceschi 1998, Lind et al. 1998, Feldt-Rasmussen 2001, Nagataki \& Nystrom 2002). However, a causal role for TSH in the initiation of thyroid cancer has not been conclusively demonstrated and it remains unclear whether serum TSH concentrations are higher as a consequence of the presence of thyroid malignancy.

An alternative explanation is that patients with lower TSH concentrations already have or are progressing towards the development of one or more autonomously functioning thyroid nodules, thyroid autonomy having long been recognised as indicative of benign disease (Mann 1998, Hegedus et al. 2003). The relationship between thyroid autoimmunity and thyroid cancer has also been investigated with several studies indicating higher cancer risk in patients with Hashimoto's thyroiditis, which itself is associated with a rising TSH (Okayasu et al. 1995, Singh et al. 1999, Cipolla et al. 2005, Kurukahvecioglu et al. 2007). 
In this issue of Endocrine-Related Cancer, Fiore et al. (2009) investigated 10178 patients presenting with nodular thyroid disease and submitted to fineneedle aspiration biopsy. They report higher TSH concentrations in those with a diagnosis of PTC when compared with those with benign thyroid nodular disease (BTND), both in patients with a clinical diagnosis of multinodular goitre and in those presenting with solitary nodules. Moreover, they observed a significant age-dependent development of thyroid autoimmunity in subjects with BTND, but not in those with PTC. Serum TSH concentrations were significantly higher in PTC patients regardless of the presence of thyroid auto-antibodies and the authors conclude that thyroid autonomy protects against the risk of PTC, while thyroid autoimmunity does not play a significant role. This paper is certainly a very valuable addition to the current literature regarding this topic, although the question regarding a causal role for raised serum TSH concentrations in thyroid carcinogenesis remains unclear. This commentary aims to place the data from Fiore et al. in context, taking the available evidence into consideration, and to identify key questions that remain unanswered.

\section{The TSH receptor in benign and malignant thyroid tumours}

There are several lines of evidence in favour of an association between TSH and thyroid cancer. Benign and malignant thyroid tumours express functional TSH receptors on the plasma membrane (Ichikawa et al. 1976), and in vitro studies have indicated that TSH increases adenylate cyclase activity leading to cAMP production and cell growth through stimulation of these receptors (Carayon et al. 1980, Chang et al. 1988). Differentiated thyroid cancers usually retain responsiveness to $\mathrm{TSH}$, and suppressive doses of $\mathrm{L}-\mathrm{T}_{4}$ administered orally can be used to inhibit the progression of metastatic thyroid cancer (Balme 1954, Simpson et al. 1988) as well as to decrease rates of recurrence in patients treated with surgery and radioactive iodine (Mazzaferri \& Jhiang 1994, Mazzaferri 1999, Biondi et al. 2005). A retrospective study has shown that undetectable TSH values were associated with longer relapse-free survival and that TSH suppression is an independent predictor of recurrence (Pujol et al. 1996). Furthermore, suppressive doses of $\mathrm{T}_{4}$ improve overall survival in high-risk patients (Sanders \& Cady 1998). Current clinical management guidelines emphasise the important role for TSH suppression in the management of patients with differentiated thyroid cancer (Cooper et al. 2006, BTA and RCP guidelines 2007).

The role of serum TSH concentrations has also been extensively evaluated in thyroid nodules with a number of studies indicating a reduction in the rate of growth and prevention of new nodule formation in patients undergoing TSH suppression (Papini et al. 1998, Zelmanovitz et al. 1998, Vermiglio et al. 2003, Gharib 2004). In addition, suppressive doses of $\mathrm{L}^{-\mathrm{T}_{4}}$ may induce beneficial cytological changes in thyroid nodules (Vermiglio et al. 2003).

Despite these findings, there are a number of arguments to be made against a role for TSH in the development or progression of thyroid cancers. First, TSH receptor mutations in regions functionally associated with increased signal transduction do not commonly occur in thyroid carcinomas (Matsuo et al. 1993). Second, in vitro studies have shown that other growth factors such as insulin-like growth factor-I (IGF-I) have been shown to be more potent in stimulating thyroid cancer growth (Derwahl et al. 1999, Mazzaferri 2000), and TSH requires cooperation with insulin/IGF-1 to exert its proliferative effects (Kimura et al. 2001). Third, there is an inverse relationship between TSH receptor mRNA levels and cancer aggressiveness (Shi et al. 1993). Fourth, thyroid cancer is known to occur in subjects with a range of TSH concentrations including in the suppressed contralateral lobe of hyperfunctioning nodules (Satta et al. 1993). Finally, a recent genome-wide association study has indicated that serum TSH concentrations are lower in patients carrying one of two alleles associated with an increased risk of both papillary and follicular thyroid cancer (Gudmundsson et al. 2009). Taken together, these findings suggest that stimulation of the TSH receptor via increased serum TSH concentrations may play a role in the growth of benign and malignant thyroid tumours, although it is unlikely that TSH acts in isolation. It has been proposed that direct thyroid hormone-dependent cellular effects rather than TSH-mediated mechanisms are responsible for the beneficial effects in patients treated with suppressive $\mathrm{T}_{4}$ therapy (Brabant 2008).

\section{Serum TSH as a biochemical predictor of thyroid cancer}

A number of reports have identified baseline serum TSH concentrations as a predictor of the diagnosis of malignancy in patients with thyroid nodules (Table 1). The first study, performed in our group, investigated 1500 euthyroid subjects presenting with thyroid enlargement and undergoing fine-needle aspiration 
biopsy. The risk of diagnosis of malignancy rose in parallel with the serum TSH at presentation with significant increases evident in those with TSH $>0.9 \mathrm{mIU} / 1$ compared with those with lower TSH concentrations (Boelaert et al. 2006). For the first time, we identified serum TSH concentration as an independent predictor of the presence of thyroid malignancy in addition to patients' age and gender as well as the goitre type evident on clinical examination. The lowest risk of malignancy was evident in patients with subclinical hyperthyroidism $(n=182$, $\mathrm{TSH}<0.4 \mathrm{mIU} / \mathrm{l}$ ), and the prevalence of thyroid cancer was highest in those with subclinical hypothyroidism $(n=27, \mathrm{TSH}>5.5 \mathrm{mIU} / \mathrm{l})$. Further analysis indicated significantly increased odds ratios for the presence of malignancy, even for TSH concentrations within the normal range (Boelaert et al. 2006).

These findings were subsequently confirmed by others. Haymart et al. investigated 843 patients undergoing surgery and recorded the preoperative serum TSH concentration. The likelihood of malignancy was $16 \%$ when TSH was $<0.06 \mathrm{mIU} / \mathrm{l}, 25 \%$ for TSH between 0.40 and $1.39 \mathrm{mIU} / 1,35 \%$ for TSH between 1.40 and $4.99 \mathrm{mIU} / \mathrm{l}$ and $52 \%$ in those with TSH of $5.0 \mathrm{mIU} / \mathrm{l}$ or greater (Haymart et al. 2008a). A further study by Polyzos et al. (2008) reported significantly increased adjusted odds ratios for the diagnosis of malignancy in those with TSH 1.5-4.0 mIU/l when compared with those with lower serum TSH concentrations at presentation. Finally, a report of a small series of 50 euthyroid patients undergoing thyroidectomy for a variety of reasons has confirmed increased risk of cancer diagnosis in subjects with serum TSH concentrations in the upper three quartiles of TSH values, compared with patients whose serum TSH was in the lower quartile. Furthermore, those who were subsequently diagnosed with thyroid cancer had lower serum concentrations of total tri-iodothyronine ( $\mathrm{T}_{3}$; Jonklaas et al. 2008). Taken together, these findings suggest that serum TSH concentrations can be used as a diagnostic adjunct in the identification of high-risk patients who require further investigation and/or surgical intervention.

\section{Association between serum TSH and differentiated thyroid cancer stage}

Haymart et al. demonstrated that higher preoperative serum TSH concentrations were not only associated with the incidence of differentiated thyroid cancer, but also with more advanced cancer stage at diagnosis. Mean serum TSH levels were significantly higher in those with stage III and IV disease when compared with those with more localised (stage I and II) disease (Haymart et al. 2008a). In this month's issue, Fiore et al. confirm the finding of higher serum TSH in patients with T3-T4 tumour stage compared with those with stage T1-T2. Furthermore, median serum TSH concentrations were significantly higher in those with lymph node metastases compared with subjects without positive lymph nodes (Fiore et al. 2009). This escalating risk of advanced disease further suggests that TSH is involved in the pathogenesis or progression of thyroid cancer.

Unique among all malignancies, the majority of staging systems for well-differentiated thyroid cancers includes age as one of the key prognostic factors (Dean \& Hay 2000, Haymart 2009). In iodine-replete healthy adult populations, such as the cohort investigated by Haymart et al. (2008a), there is an increase in serum TSH with advancing age (Surks \& Hollowell 2007, Haymart et al. 2008b). Further analysis of this cohort confirmed an association between advanced stage disease and higher serum TSH concentrations, independent of age. In addition, there was a significant correlation between higher TSH levels and extrathyroidal extension, but not with other factors associated with poor prognosis including age $>45$ years, tumour size $>4 \mathrm{~cm}$ and presence of distant metastases. These findings raise the intriguing question whether higher serum TSH concentrations stimulate thyroid cancer invasion thereby facilitating extrathyroidal extension of disease.

\section{Serum TSH concentrations and development of thyroid autonomy}

Thyroid nodules with autonomous function are less likely to harbour malignancy (Hegedus et al. 2003, Hegedus 2004). In accordance with this, we (Boelaert et al. 2006) and others (Haymart et al. 2008a, Polyzos et al. 2008) found the lowest rates of thyroid malignancy in those with TSH concentrations below the normal reference range, suggestive of the presence of thyroid autonomy (Ross 2006). The lower cancer incidence may be explained by the findings that the constitutive activating mutations of the TSH receptors, frequently found in these nodules, drive the cAMP pathways through $\mathrm{G} \alpha$ s and very rarely the cancer-associated Rasdependent MAPK pathway through $\mathrm{G} \beta \gamma$ and phosphatidylinositol 3-kinase- $\gamma$ (Du Villard et al. 2000).

Fiore et al. investigated the relationship between serum TSH and autonomous thyroid function in more detail. They found a significant age-dependent development of thyroid autonomy ( $\mathrm{TSH}<0.4 \mu \mathrm{U} / \mathrm{ml})$ in patients with benign thyroid disease, but this 
reduction of TSH with age was less evident in those with PTC. Furthermore, in patients with multinodular goitre, the frequency of thyroid autonomy was higher and the risk of PTC was lower than in those with solitary nodules (Fiore et al. 2009). Clearly, the observed decrease in serum TSH with age is at odds with data from the NHANES III survey (Hollowell et al. 2002, Aoki et al. 2007, Surks \& Hollowell 2007) and one explanation may be relative iodine deficiency in the cohort investigated by Fiore et al. Others have shown higher frequency of thyroid nodularity and autonomy in older people with long-standing iodine deficiency (Fenzi et al. 1985, Aoki et al. 2007). A further explanation for the finding of decreased serum TSH in older patients is that the NHANES cohort included patients with and without nodules, whereas the current study (Fiore et al. 2009) only includes patients with thyroid nodules. The authors propose that the finding of higher serum TSH in patients with malignant thyroid disease is mainly related to a reduction of serum TSH in those with nodular goitre rather than an increase in TSH in subjects with PTC. Although the development of thyroid autonomy may slow down cancer progression, the escalating cancer risk within patients with TSH in the euthyroid and hypothyroid reference range remains unexplained.

\section{Autoimmune thyroid disease and thyroid cancer}

Several studies have investigated the relationship between thyroid autoimmunity and differentiated thyroid cancer (Holm et al. 1985, Walker \& Paloyan 1990, Baker 1995). Although not all studies are in agreement, a meta-analysis of ten studies showed a 2.77-fold increased incidence of thyroid cancer in patients with antibody evidence of Hashimoto's thyroiditis, compared with control populations (Singh et al. 1999). Similar to the controversy in Hashimoto's thyroiditis, there is an ongoing debate about the association between Graves' disease and thyroid cancer incidence, and aggressiveness (Filetti et al. 1988, Hales et al. 1992, Pellegriti et al. 1998, Yano et al. 2007). Because Hashimoto's is often associated with progression to hypothyroidism and thus elevated serum TSH concentration and because TSH receptor stimulation is crucial to the pathogenesis of Graves' disease, it is possible that humoral thyroid autoimmunity is linked to thyroid cancer through the TSH receptor.

We found significantly higher rates of cancer in patients with detectable thyroid peroxidase antibodies compared with those in whom antibodies were absent, although antibody status was not an independent predictor of malignancy (Boelaert et al. 2006). In addition, Haymart et al. (2008b) found a significant association between pathological Hashimoto's thyroiditis and higher TSH levels, although thyroid antibody status was not determined in the patients investigated. In the current study by Fiore et al. (2009), the frequency of thyroid cancer was not significantly different between antibody-positive and antibodynegative patients, and higher serum TSH concentration was found in those with PTC when compared with subjects with benign disease regardless of antibody status. Taken together, the currently available data do not rule out an association between autoimmunity and thyroid cancer, but indicate that the mechanisms underlying the relationship between high serum TSH and thyroid cancer are different from those affecting the link between autoimmune thyroid disease and thyroid cancer. Clearly, further studies evaluating the role of autoimmune processes in the development and progression of thyroid cancer are required to support this.

\section{Conclusions}

There is increasing evidence that higher serum TSH concentrations are found in patients with thyroid nodules harbouring malignancy. In addition, baseline serum TSH levels are higher in patients with more aggressive thyroid cancer, regardless of age. Several studies have indicated that inclusion of serum TSH concentrations may be useful when evaluating the risk of thyroid malignancy in patients with nodular thyroid disease. The mechanisms underlying these observations have not been fully explained, although TSH is a known growth factor for thyroid cells and animal data have demonstrated that TSH suppression in rats exposed to radioiodine prevents the formation of thyroid cancer (Goldberg et al. 1964, Brewer et al. 2007). In addition, a few mouse models have suggested a carcinogenic role for TSH (Brewer et al. 2007, Yeager et al. 2007), although there is no evidence for a direct oncogenic role of TSH in human thyroid carcinogenesis.

In this issue, Fiore et al. present their findings in a large number of patients with thyroid nodules, confirming higher serum TSH concentrations in those with a diagnosis of PTC. In addition, their data indicate a lower incidence of thyroid cancer in patients with evidence of thyroid autonomy. The authors suggest that the development of thyroid autonomy, by reducing serum TSH concentrations, may represent a form of self-treatment similar to the use of suppressive doses 
of $\mathrm{L}_{\mathrm{T}} \mathrm{T}_{4}$ in the long-term management of patients with thyroid cancer. Although plausible, this hypothesis does not explain the findings of higher rates of malignancy in patients with TSH levels in the upper half of the normal range as well as in those with subclinical and overt hypothyroidism. Further studies evaluating the role of TSH in the initiation as well as the progression of thyroid cancer are required.

\section{Declaration of interest}

The author declares that there is no conflict of interest that could be perceived as prejudicing the impartiality of the research reported.

\section{Funding}

Dr Boelaert is supported by a Clinician Scientist fellowship from the Medical Research Council (grant number: G0601811).

\section{References}

Aoki Y, Belin RM, Clickner R, Jeffries R, Phillips L \& Mahaffey KR 2007 Serum TSH and total $\mathrm{T}_{4}$ in the United States population and their association with participant characteristics: National Health and Nutrition Examination Survey (NHANES 1999-2002). Thyroid 17 1211-1223.

Baker JR Jr 1995 The immune response to papillary thyroid cancer. Journal of Clinical Endocrinology and Metabolism 80 3419-3420.

Balme HW 1954 Metastatic carcinoma of the thyroid successfully treated with thyroxine. Lancet 266 812-813.

Belfiore A, La Rosa GL, La Porta GA, Giuffrida D, Milazzo G, Lupo L, Regalbuto C \& Vigneri R 1992 Cancer risk in patients with cold thyroid nodules: relevance of iodine intake, sex, age, and multinodularity. American Journal of Medicine 93 363-369.

Biondi B, Filetti S \& Schlumberger M 2005 Thyroidhormone therapy and thyroid cancer: a reassessment. Nature Clinical Practice. Endocrinology and Metabolism $132-40$.

Boelaert K, Horacek J, Holder RL, Watkinson JC, Sheppard MC \& Franklyn JA 2006 Serum thyrotropin concentration as a novel predictor of malignancy in thyroid nodules investigated by fine-needle aspiration. Journal of Clinical Endocrinology and Metabolism 91 4295-4301.

Brabant G 2008 Thyrotropin suppressive therapy in thyroid carcinoma: what are the targets? Journal of Clinical Endocrinology and Metabolism 93 1167-1169.

Brewer C, Yeager N \& Di CA 2007 Thyroid-stimulating hormone initiated proliferative signals converge in vivo on the mTOR kinase without activating AKT. Cancer Research 67 8002-8006.
British Thyroid Association and Royal College of Physicians 2007 Guidelines for the management of thyroid cancer. edn 2. www.british-thyroid-association.org.

Carayon P, Thomas-Morvan C, Castanas E \& Tubiana M 1980 Human thyroid cancer: membrane thyrotropin binding and adenylate cyclase activity. Journal of Clinical Endocrinology and Metabolism 51 915-920.

Chang TC, Kuo SH, Liaw KY, Chang CC \& Chen FW 1988 Cell kinetics, DNA content and TSH receptor-adenylate cyclase system in differentiated thyroid cancer. Clinical Endocrinology 29 477-484.

Cipolla C, Sandonato L, Graceffa G, Fricano S, Torcivia A, Vieni S, Latteri S \& Latteri MA 2005 Hashimoto thyroiditis coexistent with papillary thyroid carcinoma. American Surgeon 71 874-878.

Cooper DS, Doherty GM, Haugen BR, Kloos RT, Lee SL, Mandel SJ, Mazzaferri EL, McIver B, Sherman SI \& Tuttle RM 2006 Management guidelines for patients with thyroid nodules and differentiated thyroid cancer. Thyroid 16 1-33.

Davies L \& Welch HG 2006 Increasing incidence of thyroid cancer in the United States, 1973-2002. Journal of the American Medical Association 295 2164-2167.

Dean DS \& Hay ID 2000 Prognostic indicators in differentiated thyroid carcinoma. Cancer Control 7 229-239.

Derwahl M, Broecker M \& Kraiem Z 1999 Clinical review 101: thyrotropin may not be the dominant growth factor in benign and malignant thyroid tumors. Journal of Clinical Endocrinology and Metabolism 84 829-834.

Feldt-Rasmussen U 2001 Iodine and cancer. Thyroid $\mathbf{1 1}$ 483-486.

Fenzi GF, Ceccarelli C, Macchia E, Monzani F, Bartalena L, Giani C, Ceccarelli P, Lippi F, Baschieri L \& Pinchera A 1985 Reciprocal changes of serum thyroglobulin and TSH in residents of a moderate endemic goitre area. Clinical Endocrinology 23 115-122.

Filetti S, Belfiore A, Amir SM, Daniels GH, Ippolito O, Vigneri R \& Ingbar SH 1988 The role of thyroid-stimulating antibodies of Graves' disease in differentiated thyroid cancer. New England Journal of Medicine 318 753-759.

Fiore E, Rago T, Provenzale MA, Scutari M, Ugolini C, Basolo F, Di Coscio G, Berti P, Grasso L, Elisei R, Pinchera A \& Vitti P 2009 Lower levels of TSH are associated to a lower risk of papillary thyroid cancer in patients with thyroid nodular disease: thyroid autonomy may play a protective role. Endocrine-Related Cancer 16 1251-1260.

Franceschi S 1998 Iodine intake and thyroid carcinoma - a potential risk factor. Experimental and Clinical Endocrinology and Diabetes 106 S38-S44.

Gharib H 2004 Changing trends in thyroid practice: understanding nodular thyroid disease. Endocrine Practice 10 31-39.

Goldberg RC, Lindsay S, Nichols CW Jr \& Chaikoff IL 1964 Induction of neoplasms in thyroid glands of rats by subtotal thyroidectomy and by the injection of one microcurie of I-131. Cancer Research 24 35-43. 
Gudmundsson J, Sulem P, Gudbjartsson DF, Jonasson JG, Sigurdsson A, Bergthorsson JT, He H, Blondal T, Geller F, Jakobsdottir M et al. 2009 Common variants on 9q22.33 and $14 q 13.3$ predispose to thyroid cancer in European populations. Nature Genetics 41 460-464.

Hales IB, McElduff A, Crummer P, Clifton-Bligh P, Delbridge L, Hoschl R, Poole A, Reeve TS, Wilmshurst E \& Wiseman J 1992 Does Graves' disease or thyrotoxicosis affect the prognosis of thyroid cancer. Journal of Clinical Endocrinology and Metabolism 75 886-889.

Haymart MR 2009 Understanding the relationship between age and thyroid cancer. Oncologist 14 216-221.

Haymart MR, Repplinger DJ, Leverson GE, Elson DF, Sippel RS, Jaume JC \& Chen H $2008 a$ Higher serum thyroid stimulating hormone level in thyroid nodule patients is associated with greater risks of differentiated thyroid cancer and advanced tumor stage. Journal of Clinical Endocrinology and Metabolism 93 809-814.

Haymart MR, Glinberg SL, Liu J, Sippel RS, Jaume JC \& Chen H $2008 b$ Higher serum TSH in thyroid cancer patients occurs independent of age and correlates with extrathyroidal extension. Clinical Endocrinology [in press].

Hegedus L 2004 Clinical practice. The thyroid nodule. New England Journal of Medicine 351 1764-1771.

Hegedus L, Bonnema SJ \& Bennedbaek FN 2003 Management of simple nodular goiter: current status and future perspectives. Endocrine Reviews 24 102-132.

Hollowell JG, Staehling NW, Flanders WD, Hannon WH, Gunter EW, Spencer CA \& Braverman LE 2002 Serum TSH T(4), and thyroid antibodies in the United States population (1988 to 1994): National Health and Nutrition Examination Survey (NHANES III). Journal of Clinical Endocrinology and Metabolism 87 489-499.

Holm LE, Blomgren H \& Lowhagen T 1985 Cancer risks in patients with chronic lymphocytic thyroiditis. New England Journal of Medicine 312 601-604.

Hovens GC, Stokkel MP, Kievit J, Corssmit EP, Pereira AM, Romijn JA \& Smit JW 2007 Associations of serum thyrotropin concentrations with recurrence and death in differentiated thyroid cancer. Journal of Clinical Endocrinology and Metabolism 92 2610-2615.

Ichikawa Y, Saito E, Abe Y, Homma M \& Muraki T 1976 Presence of TSH receptor in thyroid neoplasms. Journal of Clinical Endocrinology and Metabolism 42 395-398.

Jonklaas J, Sarlis NJ, Litofsky D, Ain KB, Bigos ST, Brierley JD, Cooper DS, Haugen BR, Ladenson PW, Magner J et al. 2006 Outcomes of patients with differentiated thyroid carcinoma following initial therapy. Thyroid 16 1229-1242.

Jonklaas J, Nsouli-Maktabi H \& Soldin SJ 2008 Endogenous thyrotropin and triiodothyronine concentrations in individuals with thyroid cancer. Thyroid 18 943-952.

Kimura T, Van Keymeulen A, Golstein J, Fusco A, Dumont JE \& Roger PP 2001 Regulation of thyroid cell proliferation by TSH and other factors: a critical evaluation of in vitro models. Endocrine Reviews 22 631-656.

Kurukahvecioglu O, Taneri F, Yuksel O, Aydin A, Tezel E \& Onuk E 2007 Total thyroidectomy for the treatment of Hashimoto's thyroiditis coexisting with papillary thyroid carcinoma. Advances in Therapy 24 510-516.

Lind P, Langsteger W, Molnar M, Gallowitsch HJ, Mikosch P \& Gomez I 1998 Epidemiology of thyroid diseases in iodine sufficiency. Thyroid 8 1179-1183.

Mann K 1998 Evaluation of risk in autonomously functioning thyroid nodules. Experimental and Clinical Endocrinology \& Diabetes 106 S23-S26.

Marqusee E, Benson CB, Frates MC, Doubilet PM, Larsen PR, Cibas ES \& Mandel SJ 2000 Usefulness of ultrasonography in the management of nodular thyroid disease. Annals of Internal Medicine 133 696-700.

Matsuo K, Friedman E, Gejman PV \& Fagin JA 1993 The thyrotropin receptor (TSH-R) is not an oncogene for thyroid tumors: structural studies of the TSH-R and the alpha-subunit of Gs in human thyroid neoplasms. Journal of Clinical Endocrinology and Metabolism 76 1446-1451.

Mazzaferri EL 1999 An overview of the management of papillary and follicular thyroid carcinoma. Thyroid 9 421-427.

Mazzaferri EL 2000 Thyroid cancer and Graves' disease: the controversy ten years later. Endocrine Practice 6 221-225.

Mazzaferri EL \& Jhiang SM 1994 Long-term impact of initial surgical and medical therapy on papillary and follicular thyroid cancer. American Journal of Medicine 97 418-428.

Nagataki S \& Nystrom E 2002 Epidemiology and primary prevention of thyroid cancer. Thyroid 12 889-896.

Okayasu I, Fujiwara M, Hara Y, Tanaka Y \& Rose NR 1995 Association of chronic lymphocytic thyroiditis and thyroid papillary carcinoma. A study of surgical cases among Japanese, and white and African Americans. Cancer 76 2312-2318.

Papini E, Petrucci L, Guglielmi R, Panunzi C, Rinaldi R, Bacci V, Crescenzi A, Nardi F, Fabbrini R \& Pacella CM 1998 Long-term changes in nodular goiter: a 5-year prospective randomized trial of levothyroxine suppressive therapy for benign cold thyroid nodules. Journal of Clinical Endocrinology and Metabolism 83 780-783.

Pellegriti G, Belfiore A, Giuffrida D, Lupo L \& Vigneri R 1998 Outcome of differentiated thyroid cancer in Graves' patients. Journal of Clinical Endocrinology and Metabolism 83 2805-2809.

Polyzos SA, Kita M, Efstathiadou Z, Poulakos P, Slavakis A, Sofianou D, Flaris N, Leontsini M, Kourtis A \& Avramidis A 2008 Serum thyrotropin concentration as a biochemical predictor of thyroid malignancy in patients presenting with thyroid nodules. Journal of Cancer Research and Clinical Oncology 134 953-960. 
Pujol P, Daures JP, Nsakala N, Baldet L, Bringer J \& Jaffiol C 1996 Degree of thyrotropin suppression as a prognostic determinant in differentiated thyroid cancer. Journal of Clinical Endocrinology and Metabolism 81 4318-4323.

Reiners C, Wegscheider K, Schicha H, Theissen P, Vaupel R, Wrbitzky R \& Schumm-Draeger PM 2004 Prevalence of thyroid disorders in the working population of Germany: ultrasonography screening in 96,278 unselected employees. Thyroid 14 926-932.

Ron E, Lubin JH, Shore RE, Mabuchi K, Modan B, Pottern LM, Schneider AB, Tucker MA \& Boice JD Jr 1995 Thyroid cancer after exposure to external radiation: a pooled analysis of seven studies. Radiation Research 141 259-277.

Ross DS 2006 Predicting thyroid malignancy. Journal of Clinical Endocrinology and Metabolism 91 4253-4255.

Sanders LE \& Cady B 1998 Differentiated thyroid cancer: reexamination of risk groups and outcome of treatment. Archives of Surgery 133 419-425.

Satta MA, De RG, Testa A, Maussier ML, Valenza V, Rabitti C, Saletnich I, D’Ugo D \& Picciocchi A 1993 Thyroid cancer in suppressed contralateral lobe of patients with hot thyroid nodule. European Journal of Cancer 29A 1190-1192.

Shi Y, Zou M \& Farid NR 1993 Expression of thyrotrophin receptor gene in thyroid carcinoma is associated with a good prognosis. Clinical Endocrinology 39 269-274.

Simpson WJ, Panzarella T, Carruthers JS, Gospodarowicz MK \& Sutcliffe SB 1988 Papillary and follicular thyroid cancer: impact of treatment in 1578 patients. International Journal of Radiation Oncology, Biology, Physics 14 1063-1075.

Singh B, Shaha AR, Trivedi H, Carew JF, Poluri A \& Shah JP 1999 Coexistent Hashimoto's thyroiditis with papillary thyroid carcinoma: impact on presentation, management, and outcome. Surgery 126 1070-1076.

Surks MI \& Hollowell JG 2007 Age-specific distribution of serum thyrotropin and antithyroid antibodies in the US population: implications for the prevalence of subclinical hypothyroidism. Journal of Clinical Endocrinology and Metabolism 92 4575-4582.

Tunbridge WM, Evered DC, Hall R, Appleton D, Brewis M, Clark F, Evans JG, Young E, Bird T \& Smith PA 1977 The spectrum of thyroid disease in a community: the Whickham survey. Clinical Endocrinology 7 481-493.

Vander JB, Gaston EA \& Dawber TR 1968 The significance of nontoxic thyroid nodules. Final report of a 15-year study of the incidence of thyroid malignancy. Annals of Internal Medicine 69 537-540.

Vermiglio F, Lo P, Violi MA, Moleti M, Castagna MG, Finocchiaro MD, Mattina F, Mandolfino M, Zimbaro G \& Trimarchi F 2003 Changes in both size and cytological features of thyroid nodule after levothyroxine treatment. Clinical Endocrinology 59 347-353.

Du Villard JA, Wicker R, Crespo P, Russo D, Filetti S, Gutkind JS, Sarasin A \& Suarez HG 2000 Role of the cAMP and MAPK pathways in the transformation of mouse 3 T3 fibroblasts by a TSHR gene constitutively activated by point mutation. Oncogene 19 4896-4905.

Walker RP \& Paloyan E 1990 The relationship between Hashimoto's thyroiditis, thyroid neoplasia, and primary hyperparathyroidism. Otolaryngologic Clinics of North America 23 291-302.

Yano Y, Shibuya H, Kitagawa W, Nagahama M, Sugino K, Ito K \& Ito K 2007 Recent outcome of Graves' disease patients with papillary thyroid cancer. European Journal of Endocrinology 157 325-329.

Yeager N, Klein-Szanto A, Kimura S \& Di CA 2007 Pten loss in the mouse thyroid causes goiter and follicular adenomas: insights into thyroid function and Cowden disease pathogenesis. Cancer Research 67 959-966.

Zelmanovitz F, Genro S \& Gross JL 1998 Suppressive therapy with levothyroxine for solitary thyroid nodules: a double-blind controlled clinical study and cumulative meta-analyses. Journal of Clinical Endocrinology and Metabolism 83 3881-3885. 